\title{
Increasing Student Development Through Multi-Level Immersive Learning: Clemson Engineers for Developing Countries Case Study
}

\author{
Dylan Bargar \\ Graduate Student, John E. Walker \\ Department of Economics \\ Clemson University \\ dbargar@g.clemson.edu
}

Jennifer Ogle, $\mathrm{PhD}$

Associate Professor, Glenn

Department of Civil Engineering

Clemson University

ogle@g.clemson.edu

\author{
Aaron Gordon \\ Undergraduate Student, Glenn \\ Department of Civil Engineering \\ Clemson University \\ asgordo@g.clemson.edu \\ Claire Dancz, PhD \\ Research Assistant Professor, \\ Department of Engineering and \\ Science Education \\ Clemson University \\ cdancz@g.clemson.edu
}

\author{
Jeff Plumblee, PhD \\ Research Assistant Professor, \\ Department of Engineering and \\ Science Education \\ Clemson University \\ jplumbl@clemson.edu \\ David Vaughn \\ Professor of Practice, Glenn \\ Department of Civil Engineering \\ Clemson University \\ dev@g.clemson.edu
}

Abstract -Clemson Engineers for Developing Countries (CEDC) is a multi-level, immersive service-learning program that provides sustainable solutions aimed at improving the quality of life of the Central Plateau of Haiti in which students lead design, planning, and project implementation. CEDC operates under a corporate organizational structure, including vertical integration from first-year to graduate students and horizontal integration from over 30 majors, and works on between 15 and 20 projects per semester. The program also features multidisciplinary teams of 2-4 interns who live in Haiti yearround, fall and spring break trips to Haiti for groups of 10-14 students to collect data for their projects, and a course at Clemson University for students to work on their multisemester projects. The program has designed and managed over $\$ 2$ million in construction projects in Haiti, all with direct oversight and management from the CEDC interns. This paper discusses CEDC's evolution to its current state, including program formation and unique operating structure, describes a few selected infrastructure and community development projects and presents student perceptions of the program.

Index Terms - Engineering Education, Haiti, Service-learning, Water

\section{INTRODUCTION}

Employers have increasingly emphasized the need to better equip students with practical skills necessary to succeed in the workplace. These skills include written and oral communication, teamwork, ethical decision-making, critical thinking, and the ability to apply knowledge in realworld settings. ${ }^{1}$ 
Professional engineering societies and engineering accreditation boards have also acknowledged the need and revised their learning outcomes, such as issuing updates to ASCE's Civil Engineering Body of Knowledge for the 21st Century to highlight professional skills such as leadership, teamwork, communication, and globalization. ${ }^{2}$

Innovative teaching methods, such as active-learning pedagogies, are helpful in achieving these skills and learning outcomes. Forms of active-learning include project-based learning, problembased learning, service-learning, and peer-led team learning. ${ }^{3}$ This paper focuses on servicelearning, defined as "a form of experiential education in which students engage in activities that address human and community needs together with structured opportunities for reflection designed to achieve desired learning outcomes."

Service-learning in an interdisciplinary atmosphere also augments students' learning experiences. Interdisciplinary education is often considered a valuable tool within sustainability education and has the potential to add significant value to project-based learning programs by naturally involving many different academic skillsets. ${ }^{5}$ Projects may also have a greater chance of success due to the added diversity of skills and abilities and the ability for students to specialize. Achieving sustainable outcomes requires collaboration between individuals in social sciences and technical fields to adequately address community needs. ${ }^{6}$

In addition, service-learning can have significant positive impacts on students' learning experiences including: improved academic performance, development of critical values, longterm commitment to service involvement in careers, and development of other professional skills. ${ }^{7}$ Oftentimes, service-learning outcomes can be augmented with the existence of a personal working relationship with a specific community in which students can directly participate with stakeholders. ${ }^{2,8}$ Service-learning projects can also incorporate positive aspects of project-based learning, such as flexibility and structured independence. ${ }^{9,10}$ Service-learning often encourages students to develop and practice teamwork skills by having students collaboratively participate in projects. ${ }^{11}$

Service-learning can enhance learning outcomes related to cultural sensitivity, increased self-awareness of one's own cultural values, critical thinking, and problem solving. ${ }^{12}$ Studies have found strong correlations between student participation in service-learning activities and the ability to function in the complexity of the workplace. ${ }^{13}$

However, both project and service-learning have their own set of inherent challenges. Project-based learning in general "requires considerable knowledge, effort, persistence, and selfregulation on the part of the students" which necessitates engaged instructors and a structured framework for project flow. ${ }^{14}$ Service-learning approaches require considerable time investments, course flexibility, and dedication on behalf of instructors. ${ }^{15}$ Additionally, impactful and effective projects often span multiple semesters and years, creating challenges with student attrition and sustained community engagement. ${ }^{16}$

CEDC, a project and service-learning based program, has operated exclusively in Haiti by developing long-term relationships with local communities. This required building partnerships with existing NGOs and communities. The intricate nature of these partnerships was an important component of the organization and its goals, which is consistent with other successful organizations operating in developing countries. ${ }^{17}$

CEDC employs a unique structure to provide a multi-level immersive experience, helping students effectively achieve project outcomes and student learning outcomes. The course creates a vertically-integrated atmosphere for students of all majors to collaborate and relies on the 
expertise of engaged faculty members throughout the university and industry advisors throughout the local community to provide students with support on technical concepts. Faculty and industry advisors' time is spent mentoring students, maintaining community relationships, providing administrative support, and conducting research. The structure allows students to assume administrative responsibility and develop positive service-learning and active-learning outcomes while allowing instructors to focus on program level strategic direction and CEDCrelated research.

\section{CEDC History, Formation AND EvOLUTION}

CEDC formed organically when a small group of undergraduate and graduate engineering students showed an interest in using their technical skills to serve in an international context. The students could not find a natural fit with existing programs at Clemson University. Instead of attempting to force a fit in an existing program, the students began searching for external opportunities. After recruiting a faculty advisor to help identify opportunities and provide guidance, the students outlined criteria for selecting a viable project including: safety and security of the site, students' ability to use their education to contribute to projects, the potential for partnership with a funding partner and host community, and travel cost.

A few months later, a local religious organization approached the faculty advisor with a request for engineering expertise to upgrade and replace a water distribution system in Cange, Haiti. The original water system was built in 1984, which used a dam and turbine pump to power a piston pump to deliver 50 gallons per minute approximately 1,100 feet up a mountain to two cisterns. The water was then gravity-fed to six fountains throughout the community. The water system had been in continuous operation for 25 years; it was deteriorating, in need of expansion, and lacked water filtration and treatment. Initial discussions were productive, and shortly thereafter, the student leader traveled with a volunteer engineer from the religious organization to the project site in Cange, Haiti. The student found that the site had secure living quarters with transportation and logistics provided by a large US-based NGO. Working with the NGO provided the university with sufficient risk management to approve travel for students and faculty. In addition, the project appeared to be challenging, yet one that the students could use their engineering backgrounds to solve. In June 2009, a group of six students traveled to Cange to perform assessments and survey the site. This information would be used to begin a course in fall 2009.

In fall 2009, the students formed the student-driven organization and associated class. The faculty advisor provided engineering expertise where needed, helped troubleshoot organizational challenges, and helped minimize administrative barriers. Shortly thereafter, students partnered with a local engineer, who became an industry advisor and provided further project and organizational guidance.

In early 2010, a massive earthquake killed thousands in Haiti and destroyed most of the infrastructure in the capital city, Port-au-Prince. Cange did not experience any damage from the earthquake, but due to the severely damaged hospitals and homes in Port-au-Prince, a portion of the population (many of whom were injured) migrated to the area surrounding the medical compound in Cange. Nine months later, in October 2010, a major cholera outbreak began in a city near Cange, quickly spreading throughout the country. These events increased the urgency of the project and highlighted the need for water treatment. 
To better serve Haiti and diversify disciplines and skillsets, CEDC started recruiting outside of engineering, seeking students in marketing, graphic communications, accounting, and other business-oriented fields. At this time, CEDC students were predominately seniors and graduate students so by the time students understood the cultural context and scope of the project, they graduated and left the program. The need for more continuity within the program led CEDC to begin recruiting first- and second-year students, vertically integrating the organization from freshman undergraduates to doctoral students. More experienced students provided mentorship and training to first-year students. This resulted in the organization becoming a corporate organizational structure, which will be discussed in the following section.

From 2010 to 2011, delegations of six-to-eight students and one advisor traveled to Cange each fall and spring break. During these trips, students inspected construction, delivered and discussed new design documents with the community, and identified new needs, concerns or challenges. Unfortunately, miscommunication and alternative construction practices led to a significant amount of rework under this method of delivery and inspection. There was a significant cultural and technological challenge between the American engineers and Haitian contractors during construction that led to deviations from the specifications and design. For example, Haitian construction practices do not focus on concrete mixing and proportioning, a crucial aspect of achieving structural integrity of a reinforced concrete building. In addition, complex design criteria with regard to installing the pump and turbine required a project manager with a technical engineering and construction management background in order to effectively and efficiently schedule tasks. In addition, rural Haiti lacks individuals with such backgrounds. In order to overcome these obstacles, CEDC decided to deploy a full time student intern in Cange to provide constant oversight, train the local construction crews on internationallyaccepted construction methods, and help discover and develop new projects. Beginning in May 2011, CEDC has had a near-continual student presence in Cange, with interns providing oversight and serving as the liaison to the community as the scope and scale of projects began to expand.

\section{Structure}

As the organization grew and began working on new projects, CEDC student leaders became overwhelmed by having to manage 12-15 students from various disciplines and experience levels. Additionally, new skillsets, such as management, organizational strategy, marketing, and accounting, were required to support new projects. The organization had constantly struggled to balance project workload, student skills, and funding - many of the same issues that a business would face. Students, in discussions with an industry advisor, decided that the organization should mimic a corporate organizational structure. This organizational structure can be seen in Figure 1, where orange boxes represent student roles, and blue boxes represent faculty and industry advisors.

The updated organizational structure provided student leaders with a smaller span of control and provided the order required for managing the diverse groups of students needed. Under this corporate organization structure, CEDC student leadership was able to formally address more of its internal 'business' needs, including human resources (recruiting and promotion), project accounting and finance, intern support, trip logistics, fundraising, and public relations. To fulfill these updated roles, as well as the diversification of projects, CEDC revamped its recruiting 
efforts in order to target students from over 30 majors including engineering, business, public health, computer science, among others.

The organizational structure remains flexible enough to address updated program needs (such as expanding or contracting intern support), but it still maintains the same basic corporate organizational structure that has allowed for successful controlled growth. Students may move vertically or horizontally throughout the organizational chart, with students who demonstrate responsibility and who desire leadership experiences typically moving up the organizational chart during their tenure in the program. This method for increased student responsibility allows faculty to help lead more projects than would normally be feasible.

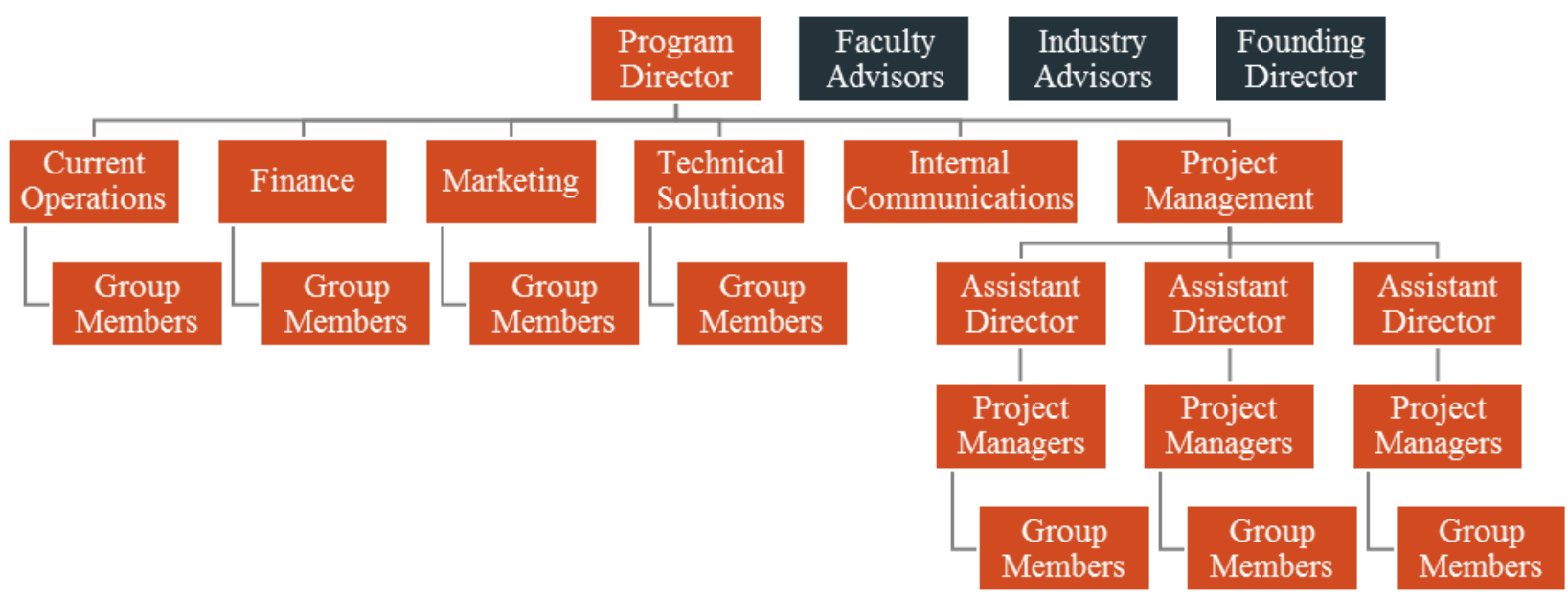

FIGURE 1

CEDC ORGANIZATIONAL STRUCTURE.

\section{Program Immersion}

CEDC has three primary levels of student immersion in the program, shown in Figure 2. At the classroom level, students take a 1 credit-hour course and participate in the program each semester, potentially beginning as early as their first year and some continuing into graduate school. Many of these students will move into leadership roles and participate in multiple projects. The different roles that students may undertake in the classroom are represented by orange boxes in Figure 1. All student positions are for credit and are unpaid, but some students have applied for and received service-oriented scholarships through the University due to their participation in CEDC.

At the student-trip level, select students may travel to sites in the Central Plateau of Haiti for five-to-ten day data collection and project execution trips during the spring, summer, and/or fall semesters. These trips help provide students the opportunity to better understand the cultural context for projects, actively collect information for their team and other teams, deliver designs and other materials to CEDC interns and the community, and participate in active projects. Students selected are typically in their second or third semester in the program, have been an active contributor to CEDC, and have demonstrated the maturity necessary to serve as an ambassador to our host community. Thus far, CEDC has funded nearly all student trips to Haiti, with the exception of student vaccinations and passports. 
For the most engaged students, CEDC offers the internship-level of involvement. The internship is one of the keystones of CEDC's program and its continued success both at Clemson University and abroad. Interns oversee all projects, serving as CEDC's field engineers, liaisons with the community, and project managers. After their internship experience, students return to the classroom and serve as invaluable assets to the program by educating other CEDC students about applied humanitarian engineering and cultural awareness. Many of CEDC's student Program Directors (the student leader of the student organization and class) first served as interns. Interns' travel and living expenses are paid by CEDC, and interns receive a nominal stipend for miscellaneous expenses.

The organizational structure and project-based learning approach prepares students for postgraduate careers as they develop the ability to not only work in interdisciplinary teams, but also gain a deep understanding of technical subjects across disciplines.

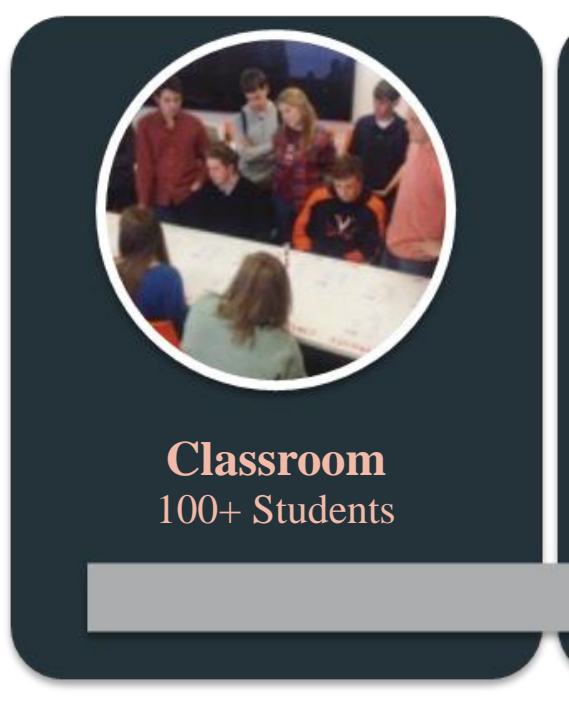

100+ Students

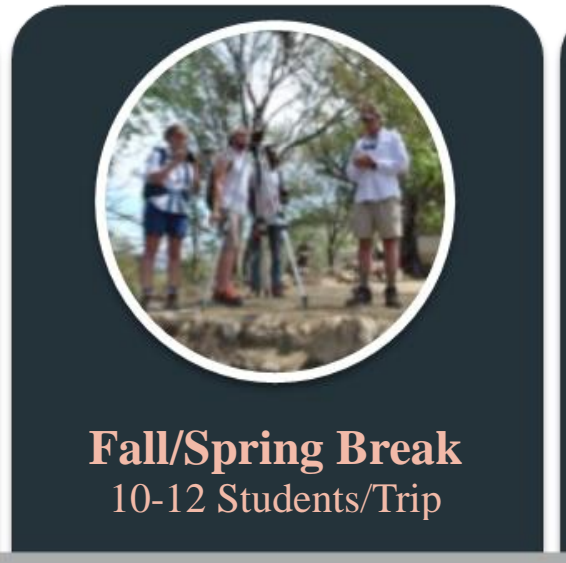

Levels of Engagement

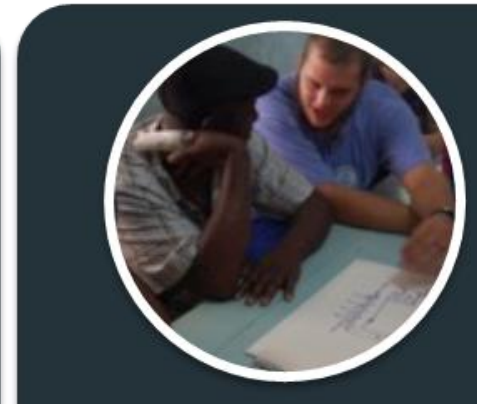

Internships in Haiti

2-4 Students

FIGURE 2.

LEVELS OF PROGRAM IMMERSION IN CEDC.

\section{Program Budget}

CEDC is largely a volunteer organization, with the bulk of program expenses funding student travel and intern expenses. Student trips cost the program approximately $\$ 1,000$ per student, and with two trips per year of 8-12 students and faculty, trip costs total nearly $\$ 24,000$ per year. Interns costs approximately $\$ 1,250$ each per month in-country, including travel costs and a $\$ 100 /$ month stipend. With two interns in Haiti year-round, intern costs total approximately $\$ 30,000$ per year. Other costs include research and development expenses, prototyping materials and equipment, printing costs, and data collection expenses. Total annual program costs are estimated in Table I. By comparison, many other programs require that students fund themselves, so in replicating the program elsewhere, travel-related expenses could be heavily reduced or eliminated if necessary.

Capital expenses, including field labor and project materials and equipment, are paid by NGO partners and are not considered CEDC program expenses. These expenses total over $\$ 2$ million since program inception in 2009. 
International Journal for Service Learning in Engineering,

Humanitarian Engineering and Social Entrepreneurship

Vol. 11, No. 2, pp. 55-71, Fall 2016

ISSN 1555-9033

TABLE I

SUMMARY OF ANNUAL CEDC PROGRAM EXPENSES

\begin{tabular}{|l|c|c|c|}
\hline \multicolumn{1}{|c|}{ Expenditure } & Unit Cost $[\$]$ & Units & $\begin{array}{c}\text { Total Cost } \\
{[\$]}\end{array}$ \\
\hline Short-term trips & & & \\
\hline Insurance (per traveler per trip) & 38.00 & 24 & 912.00 \\
\hline Flights and ground transportation (per traveler per trip) & 600.00 & 24 & $14,400.00$ \\
\hline Room and board (per day per traveler, average of 5 days) & 50.00 & 120 & $6,000.00$ \\
\hline Interns & & & \\
\hline Insurance (per intern per month) & 38.00 & 24 & 912.00 \\
\hline Flights and ground transportation (per intern per trip, 2 trips each) & 600.00 & 4 & $2,400.00$ \\
\hline Room and board (per month per intern) & 600.00 & 24 & $14,400.00$ \\
\hline Stipend (per month per intern) & 100.00 & 24 & $2,400.00$ \\
\hline Other expenses (misc. equipment, supplies and materials) & $10,000.00$ & 1 & $10,000.00$ \\
\hline TOTAL & & & \\
\hline & & & $51,424.00$ \\
\hline
\end{tabular}

\section{Project Framework}

As CEDC has grown, so has its potential to work on a variety of projects from relief and infrastructure development to health and economic development. While infrastructure and water projects continue to remain a focus for the organization, many other projects, such as developing fish hatcheries with local farmers or providing electricity for schools in very rural sections of the country, have been successfully completed. Currently, CEDC works on 15 to 20 projects per semester. These are either 'incubator' research projects primarily done in a lab setting, or operational projects, which are field-ready, practical projects that are either identified by our partners as a need or are spun out of a matured 'incubator' project once adequate sustainability, funding, and feasibility measures have been met.
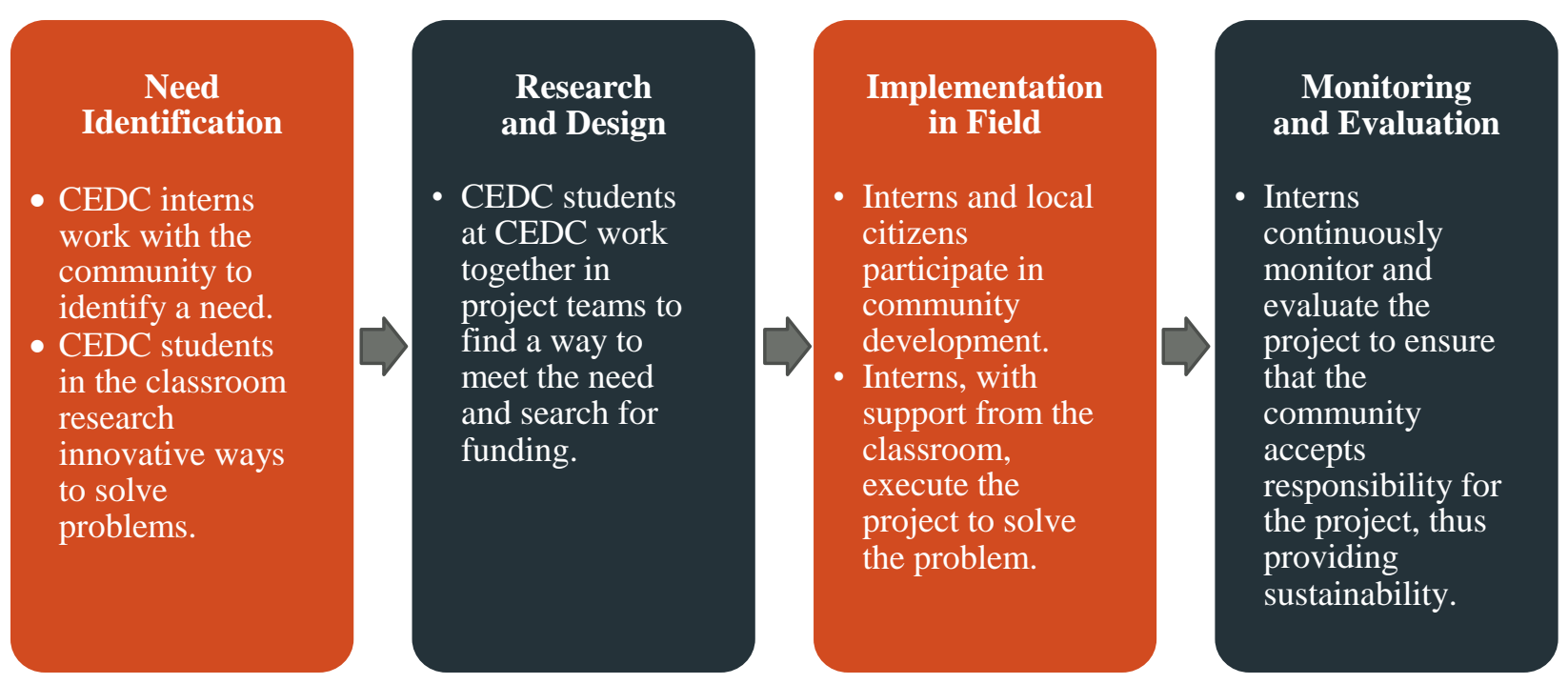

FIGURE 3.

THE CEDC SERVICE-LEARNING MODEL. 
Figure 3 describes the model under which CEDC operates. Projects begin when student interns, leadership, industry advisors and faculty members conduct a thorough needs identification of potential project areas or local community members address their needs to CEDC students in Haiti. Afterwards, interns and faculty help students create objective criteria for projects and the students begin the research and design phase while student leaders begins communications with potential funding partners. When funding is secured and designs are rigorously assessed and tested, student interns in Haiti work with students at Clemson University and local communities to implement the project. Finally, interns monitor the project and relay pertinent information and feedback back to students at Clemson University.

\section{Selected Project Outcomes}

\section{Ba Cange Water System}

When the original Cange water system renovation was completed in 2014, all residents in Cange had access to clean water through eight gravity-fed fountains throughout the community. Shortly thereafter, people surrounding Cange began traveling long distances, some upwards of three miles, to acquire water from the potable source. People living in Ba Cange (lower Cange) are situated at the source for the Cange water system (which pumps water up 1000 feet to the village of Cange), but no water was returned down the mountain for their convenient use. Rather, these individuals had to climb nearly 1,100 feet vertically up the mountainside to the nearest Cange fountain. This trek takes at least two hours round-trip due to the steep elevation change between the two villages. Beyond the person-hours wasted from this endeavor, carrying several gallons of water through mountainous Haiti can be dangerous due to uneven terrain, steep slopes, and lack of safety mechanisms such as handrails or proper stairs. In most cases, the task of retrieving water falls to women and small children, who could use this time to study, attend school, or better provide for the family.

Due to the arduous hike, many individuals still used untreated water from the source in Ba Cange or from Lake Peligre to satisfy their water needs. Both of these sources are contaminated, and drinking this water exposes individuals to numerous maladies including cholera, various species of parasites, and diarrheal diseases. Figure 6 shows results of a coliform test of the raw water from the primary Ba Cange source (along with test results after treatment). Estimates gathered from local Haitians indicated that approximately fifty families live in the Ba Cange area, with dozens of Cange citizens spending most of their day on their agricultural plot in the area as well. 


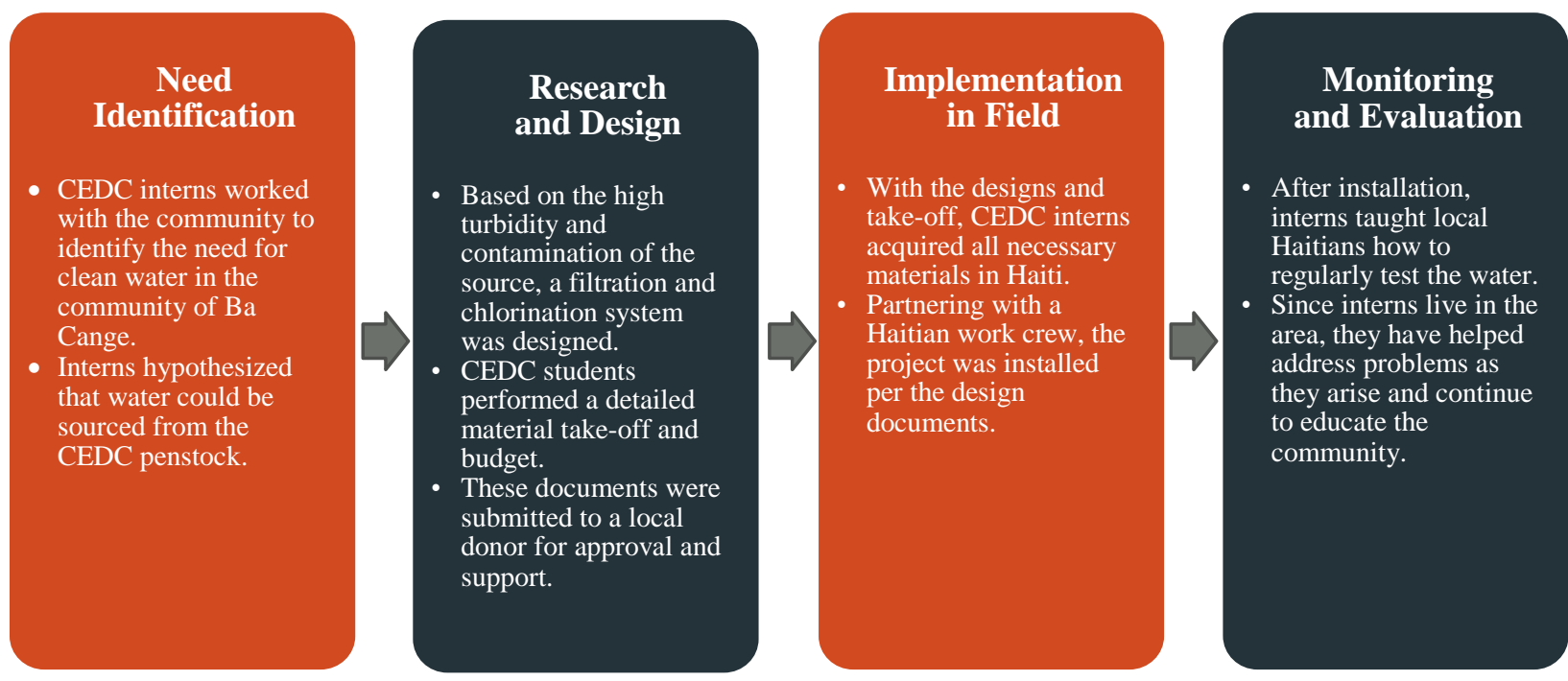

FIGURE 4.

CEDC MODEL APPLIED TO A WATER SYSTEM PROJECT IN HAITI.

The CEDC service-learning model was used to successfully execute this project as seen in Figure 4. Along with the valuable technical and industry experience from the advisors, Clemson University's engineering curriculum provided students with the capabilities to use engineering software and spreadsheets to produce final drawings and precise budgets comparable to those seen on any construction, engineering, or research project. This rigorous design process prepares students for post-graduate work by demonstrating how assignments and projects go through numerous permutations before being released and involves a large team of people rather than a single individual. CEDC's structure allowed students working on the designs to focus on the design work with advisors, while other groups focused on fundraising, transportation logistics, and other required support.

The final system was a multi-stage system. The first stage of treatment for the final design involved four large 20" cartridge filter housings with 1" inlet/outlets. The filter housings are modular, accommodating filters ranging 200 microns to 0.35 microns. These may be altered due to changes in sediment loads or availability of filters. Thirty and five micron filters were purchased for the initial three months of operation. To disinfect the water against bacteria and viruses, chlorination was used as the second stage of treatment. The system was designed with bypass lines and ball valves to allow adjustments to be made with regard to chlorine injection, with the goal to maintain an effective yet safe level, between $0.2 \mathrm{mg} / \mathrm{L}$ and $1.0 \mathrm{mg} / \mathrm{L} .{ }^{\mathrm{xv}}$ The scope, budget, and design documents were approved by the funding partner and project funds were released to CEDC student interns in Haiti in May 2015. The original design was projected to cost approximately $\$ 2,000$, with $25 \%$ of this being local labor costs, and over $50 \%$ being materials sourced in Haiti. Due to the urgency of the project, minor design changes were required to expedite procurement of materials, but prices were comparable to the initial estimates. The final budget is summarized in Table II. 
TABLE II

SUMMARY OF EXPENSES FOR THE BA CANGE WATER SYSTEM

\begin{tabular}{|c|c|}
\hline Expenditure & Amount [\$] \\
\hline PVC piping from the US & 352.54 \\
\hline Materials purchased in Haiti & $1,131.70$ \\
\hline Haitian Labor & 533.00 \\
\hline TOTAL & $2,017.24$ \\
\hline
\end{tabular}

Construction of the system began in July 2015 when the cistern and filters were mounted. During the next two days, the PVC piping and chlorinator were installed. CEDC interns spent the remainder of the week calibrating the system to achieve an ideal level of chlorine to ensure a proper residual as dictated by the World Health Organization guidelines for chlorine use. ${ }^{18}$ All labor was performed by CEDC interns or under direct CEDC intern oversight. Testing of the system was performed by CEDC interns or under the supervision of students and all data were relayed back to CEDC industry advisors in the United States. The project was not deemed complete until the system was consistently delivering safe levels of chlorine on a regular basis and no traces of fecal coliforms were detected. The final system can be seen in Figure 5 along with the filters (blue, bottom-left), the chlorinator (gray, centered), and the 125 gallon holding tank (black, top-right).

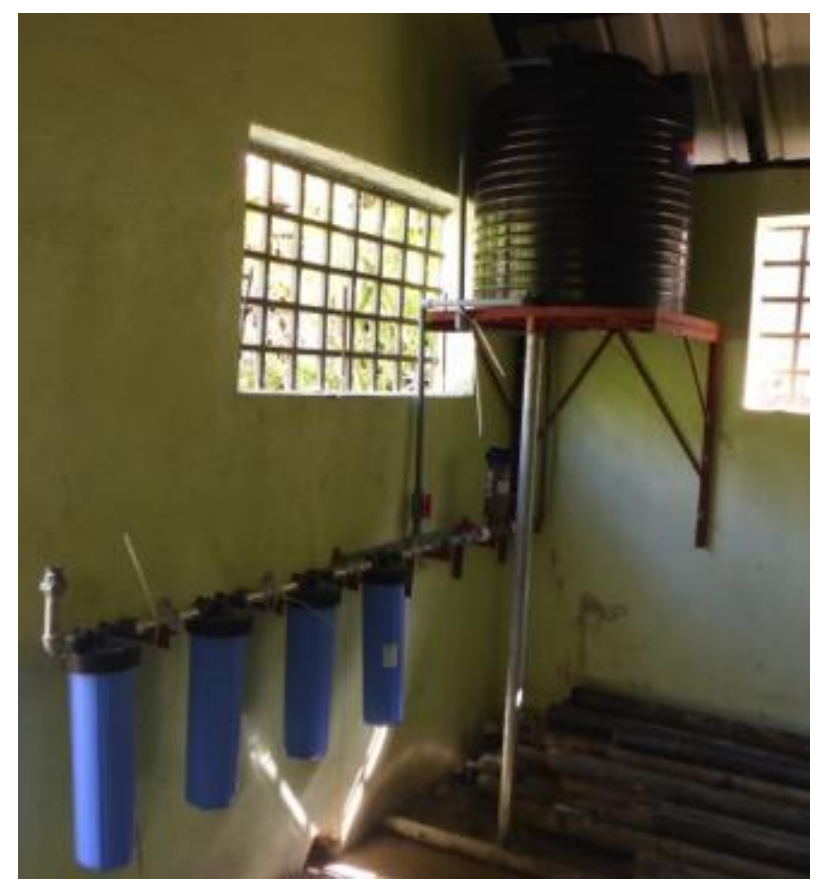

FIGURE 5

COMPLETED BA CANGE WATER TREATMENT SYSTEM.

As seen in Figure 6, the after-treatment plate revealed no presence of fecal coliforms in the water, which indicates project success; clean water is now available to the community of Ba Cange. To ensure sustainability of the system, local Haitian technicians were trained to perform water testing and chlorine measurements continue to be taken by the trained local workforce 
using a Hach colorimeter. To date, no public health assessments have been conducted in the area to identify the exact effect that the water has had on the local community. However, local citizens testify that they use the system daily and interns have witnessed the system being constantly used by everybody in the region. At the conclusion of the project, CEDC students submitted an as-built budget with receipts, photos, documentation, and testing data to the funding partners after a comprehensive review by CEDC's industry advisors.
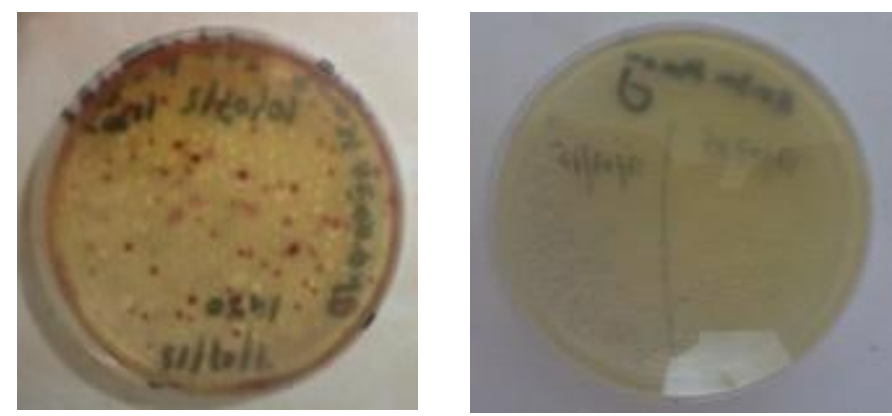

FIGURE 6

FECAL COLIFORM TESTING BEFORE (LEFT) AND AFTER (RIGHT) TREATMENT OF THE BA CANGE WATER SOURCE.

\section{Morne Michel School Repairs}

Following the completion of the original Cange water system project in 2012, it was clear that CEDC's unique approach to humanitarian engineering could be expanded beyond a single project. Consequently, CEDC interns began to perform assessments and meeting with locals in the villages surrounding Cange in order to identify other needs that could be met through the CEDC model. A majority of students in the program at that time were engineers interested in improving access to clean water for the residents of the Central Plateau, where the cholera epidemic in Haiti began, and was continuing to cripple local communities. As a result, the village assessments focused on evaluating each community's drinking water situation and the possibility of providing water treatment systems to halt the spread of this deadly disease, while simultaneously promoting safe sanitation practices. These assessments were submitted to funding partners for approval of funds to execute the intern's suggestions.

In July 2012, two CEDC interns visited the community of Morne Michel, a rural village in an extremely mountainous region. The interns drafted a report of their findings, detailing an impoverished village with no access to modern amenities such as electricity and reliable cell phone service, or even clean water. Additionally, interns noted that the rough terrain and elevation changes associated with traveling to Morne Michel would make the logistics of any construction projects in the area exceedingly difficult. With limited funds available for water projects at the time and the cholera epidemic more severe in the lower regions of the Central Plateau, CEDC's partners did not fund any of their projects in Morne Michel immediately, and consequently, there were no CEDC projects around Morne Michel for several years.

In March 2015, a team of CEDC students and interns traveled back to Morne Michel over the students' Spring Break to identify potential needs in the community. This second assessment trip to Morne Michel broadened the scope beyond water treatment projects to include any issues that villagers considered important or critical. The team spent a day discussing and planning with 
village leaders, including the head of the school, a community health worker, and the leader of the church. Several problems were identified, such as the lack of lightbulbs for students to study at night, the poor school roof that leaked during the many storms of the rainy season, the eroding school and church foundations, as well as the rocky and dangerous courtyard that led to instances of injuries to the children. The final project scope included installing solar panels at the school, pouring a concrete courtyard, and renovating the school's roof and foundation. The CEDC service-learning model was utilized to execute this project as shown in Figure 7.

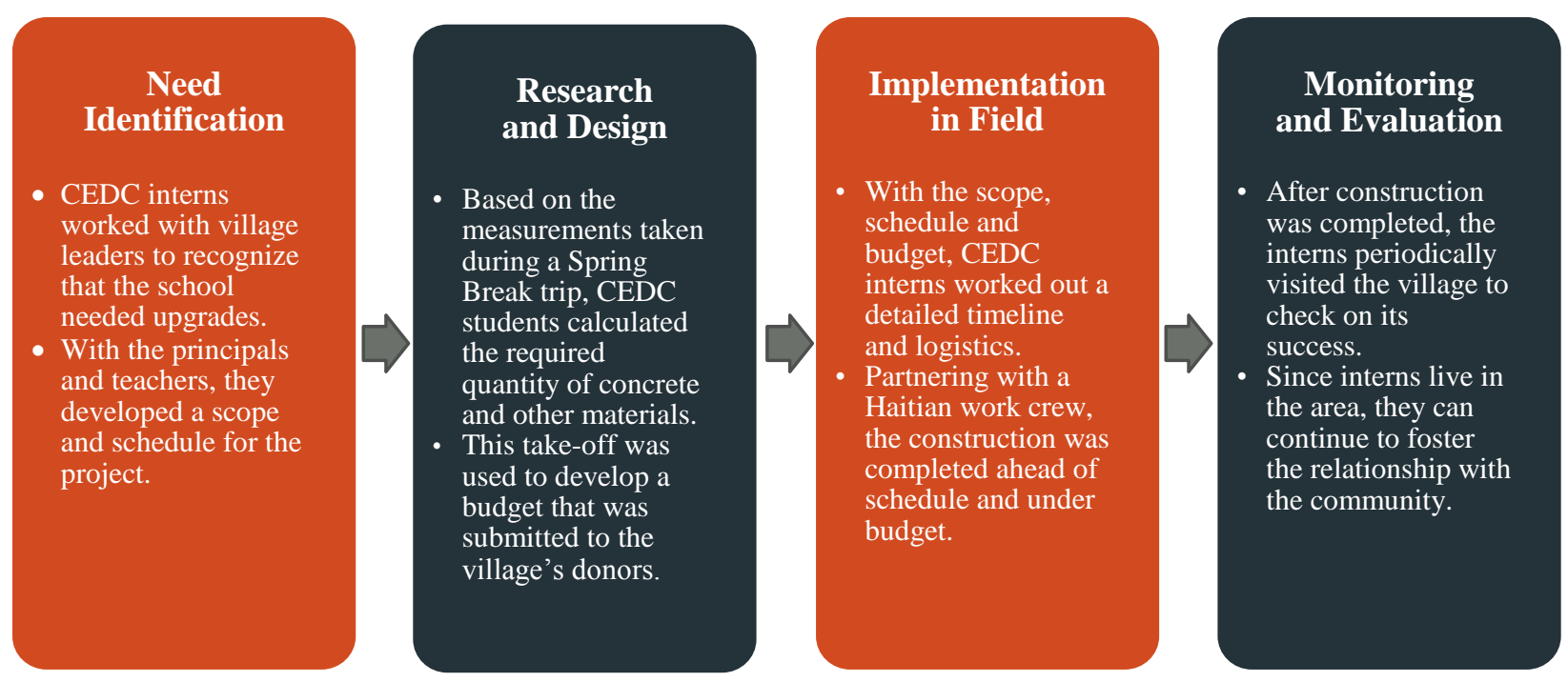

FIGURE 7.

CEDC MOdel APPLIED to A PROJECT IN THE VILLAGE OF MORNE MiCHEL IN HAITI.

As seen in Table III, the total cost for the Morne Michel Project was approximately $\$ 13,500$, with nearly $25 \%$ of the total budget being transportation of materials to the site, $33 \%$ of the budget covering local labor for construction, and the remainder for materials, tools, and equipment. This budget was subsequently approved by the funding partners. The student interns then visited Morne Michel again to propose the project to the aforementioned community leaders where it was unequivocally accepted.

TABLE III

SUMMARY OF EXPENSES FOR THE MORNE MICHEL PROJECT.

\begin{tabular}{|c|c|}
\hline Expenditure & Amount [\$] \\
\hline Materials, Tools, and Equipment & $5,730.00$ \\
\hline Transportation to Jobsite & $3,313.20$ \\
\hline Haitian Labor & $4,502.00$ \\
\hline TOTAL & $13,545.20$ \\
\hline
\end{tabular}

Due to the village's remoteness, the logistics of transporting the necessary equipment and materials to the jobsite was the most significant obstacle the interns faced. CEDC interns organized local labor to transport items including cement, wheelbarrows, and paint cans on 
various pack animals owned by residents. However, sand proved to be a difficult commodity to transport from the highway and keep due to the possibility of theft, so CEDC students decided to acquire sand and aggregate for the concrete locally from the side of an adjacent mountain. To tackle this task, a team of diggers and haulers was recruited from the local community to aid with the acquisition of material for the courtyard and school.

In April 2015, the CEDC interns and a team of specialized labor from Cange departed for Morne Michel to begin work on the first phase of the project: the courtyard, school roof, and school foundation. Local labor from the community was utilized as much as possible to bring jobs to the area and develop a sense of ownership of the project.

As seen in Figure 8, CEDC interns worked with students in the classroom to ensure project success. CEDC interns oversaw all aspects of the project in the field, ranging from resolving disputes to tracking expenses to ensuring safety for their workers and students in the Morne Michel school. Beyond the field, CEDC students in the classroom provided support to the interns by performing research, doing initial testing on new concept and designs, and presenting updates to our funding partners. Students in the classroom and interns in the field worked cooperatively to define relevant cultural considerations, explore sustainable solutions, and to investigate future projects in the region.

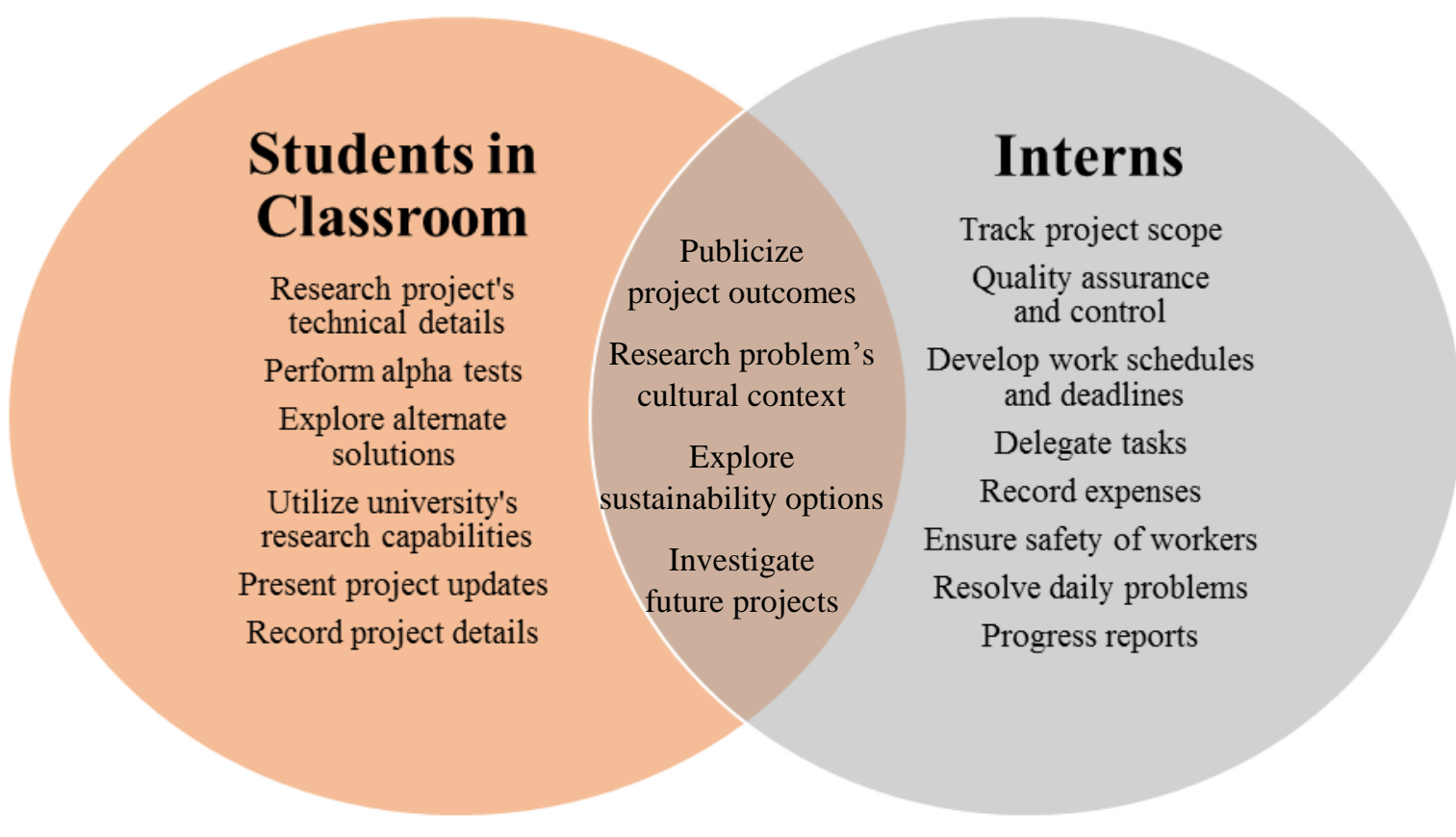

FIGURE 8

SUMMARY OF INTERN RESPONSIBILITIES DURING THE MORNE MICHEL PROJECTS.

The interns returned to their base of operations in Cange every weekend to stock up on provisions and update advisors and donors in the United States. During construction, progress was stalled on several occasions due to the difficulty of acquiring sand. In these instances, CEDC interns announced a delay to the local community, advisors, and students at Clemson University until enough sand was gathered to complete another week of work. Five weeks after construction 
broke ground, the first phase of this project was completed, including the courtyard, roof repairs, and foundation augmentation. The repaired school and new courtyard can be seen in Figure 9.

CEDC interns revisited the Morne Michel project in July 2015 in order to implement the second phase of the project - a solar-powered system of LEDs to illuminate classrooms. Students worked with industry advisors to develop a design that could satisfy the project scope of five to six LED lights in the school. The design was altered several times as CEDC interns traveled to various hardware stores in Port-au-Prince to determine what size solar panels, lightbulbs/LEDs, and wires were available. CEDC students also designed metal supports that could safely secure the solar panels at the optimal angle to catch sunlight. The panels and wiring were installed over the course of two days in mid-July with help from local students at the school in Morne Michel. A half-day was spent educating the leaders of the school on how to operate and maintain the system.

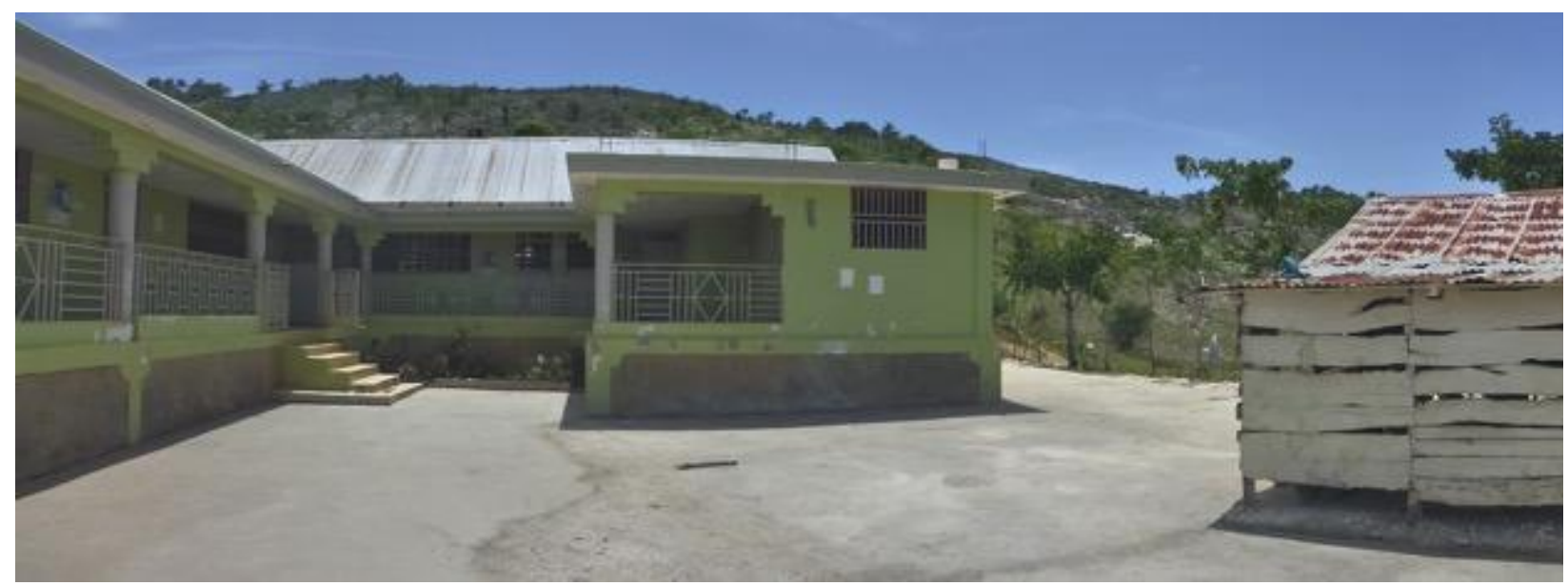

FIGURE 9

COMPLETED COURTYARD AND REPAIRED SCHOOL IN THE VILLAGE OF MORNE MICHEL.

Additional contingents traveling to the village during the past year have witnessed the students use the courtyard for everything from pick-up soccer matches to informal dance parties. The lights at the school also allow adult members of the community to take classes at night and students to complete their homework more easily. Thus far, no comprehensive survey has been conducted to assess the social ramifications of this project, although the engineering success is demonstrated by the completion of the courtyard and the operation of the small electrical system within the school. With both phases of the project completed, the CEDC students presented a full breakdown of the project with budgets, receipts, photos, and a full timeline to the funding partner. More projects are currently being proposed in the same village, including a water treatment system, an experimental plot to teach students at the school about sustainable agricultural methods, and a new church and pre-school.

\section{DISCUSSION}

The projects discussed above provided an immersive learning experience for students who designed, managed, and oversaw their implementation. Students gained valuable experience by developing detailed project scopes, budgets, and understanding and solving logistical challenges. 
These efforts included the CEDC interns in Haiti, CEDC students who traveled on a shorter spring break trip, and students in the classroom at Clemson University. Interns oversaw all construction, trained the local population, served as the liaison between the classroom and the community, performed field engineering and served as project managers. Students on the spring break trip primarily gathered information to facilitate design for these projects and future projects. Students in the classroom completed initial designs, performed initial testing and prototyping of designs, and helped troubleshoot issues from the field. CEDC's unique class structure enabled numerous students to become involved in the project planning and execution while working with professional advisors and maintaining a close relationship with the local community in Haiti.

CEDC's organizational structure facilitates integration of professionals from both academia and industry into individual projects and the program in general, providing students in Haiti the advice and guidance necessary to ensure that these projects maintained their proper scope and budget while navigating through the obstacles specific to each project. Industry professionals with practical experience were invaluable to completing the projects safely, efficiently, economically, and to desired specifications. In addition to the practical knowledge of industry professionals, student interns usually return to the class during future semesters and are able to impart their knowledge and field experiences to new student project managers, interns and program leaders through CEDC's vertical integration of graduate and undergraduate students.

In comparison to a traditional course format, this course:

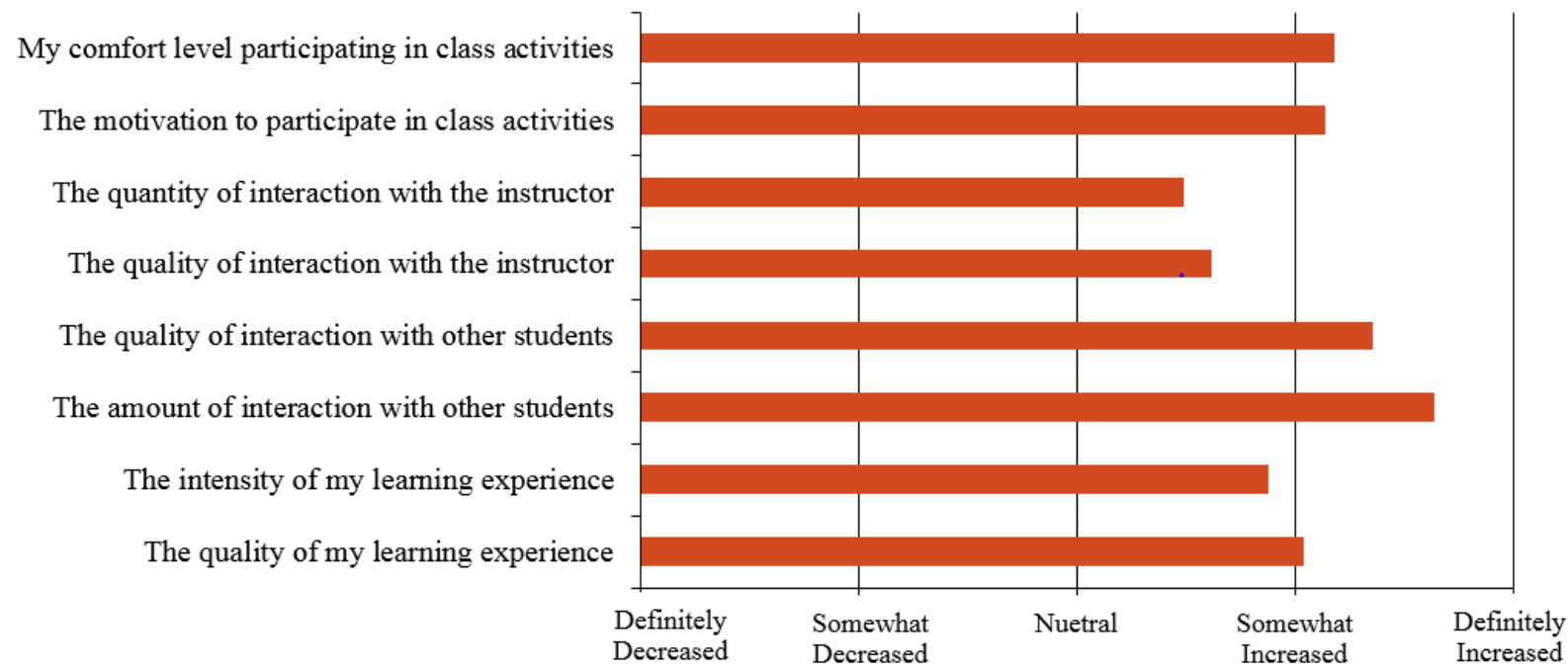

FIGURE 10

EXCERPT FROM STUDENT ASSESSMENT OF CEDC LEARNING OUTCOMES, APRIL 2016

During the fall semester of 2015 and spring semester of 2016, 86 students were surveyed on their experience in CEDC. Figure 10 shows that the projects and structure of CEDC provides positive affective outcomes for students in comparison with their traditional coursework. CEDC interns gain the most concrete lessons from the program, due to their direct exposure to more projects and extensive travel experience, but even students in the classroom and on short trips benefit by practicing the processes of designing a project and implementing it. These outcomes 
prepare students for post-graduate experience by exposing them to the vagaries and complexities of the professional world. It shows students the difficulty and frustration of creating lasting solutions in a world full of uncertainty, unsustainable practices, and inefficiencies. These learning outcomes are critical for course success and are often neglected in other courses. Students participating in CEDC projects are given a 'safe space' to practice their engineering skills with multiple levels of advisory oversight from engineers in industry and academia.

Building upon the data presented in Figure 10, future research plans include increasing the student sample size; quantifying direct measures of student learning outcomes; assessing the program impacts in the target community it seeks to serve; and comparing students in CEDC's different levels of immersion with a control group to help clarify which impacts are inherent with the program, and which are a product of a specific level of student immersion.

\section{CONCLusion}

CEDC's unique structure provides students the opportunity to participate in an immersive course and internship program to create and implement solutions for the developing world. In addition to technical learning outcomes, the team-based atmosphere and international context help students develop leadership skills, improve communication abilities, and cultivate cultural awareness. The organizational structure and faculty/industry mentorship allows students to recognize both individual and team contributions to impactful projects. Additionally, the multilevel immersive experience gives students the opportunity to gain project management experience in a developing country and within their teams at Clemson University. The innovative structure of CEDC gives a unique and impactful learning experience through leadership opportunities, technical skill applications, and student engagement in projects.

\section{REFERENCES}

1 "Falling Short? College Learning and Career Success." Selected Findings from Online Surveys of Employers and College Students Conducted on Behalf of the Association of American Colleges and Universities. Hart Research Associates. 2015.

${ }^{2}$ Plumblee, Jeffery M., Corey Cattano, Lansford Bell, and Leidy Klotz. "Fulfilling engineering program objectives through service learning campaigns in developing countries." Leadership and Management in Engineering 12, no. 2 (2012): 46-52.

${ }^{3}$ Ogle, Jennifer Harper, Jeffery M Plumblee, David E Vaughn, and Aaron S. Gordon. "Enhancing Students' Learning Experiences through Translational Research in Engineering Education." American Society for Engineering Education. 2016.

${ }^{4}$ Jacoby, Barbara. "Service-learning in today's higher education." Service-learning in higher education: Concepts and practices (1996): 3-25.

${ }^{5}$ Capraro, Mary Margaret, and Meredith Jones. "Interdisciplinary STEM project-based learning." STEM Project-Based Learning. SensePublishers, 2013. 51-58.

${ }^{6}$ Hollander, Rachelle, Adjo Amekudzi-Kennedy, Sarah Bell, Frazier Benya, Cliff Davidson, Craig Farkos, David Fasenfest et al. "Network priorities for social sustainability research and education: Memorandum of the Integrated Network on Social Sustainability Research Group." Sustainability: Science, Practice, \& Policy 12, no. 1 (2016). 
${ }^{7}$ Astin, Alexander W., Lori J. Vogelgesang, Elaine K. Ikeda, and Jennifer A. Yee. "How service learning affects students." (2000).

${ }^{8}$ McDonald, James, and Lynn A. Dominguez. "Developing university and community partnerships: A critical piece of successful service learning." Journal of College Science Teaching 44, no. 3 (2015): $52-56$.

${ }^{9}$ Thomas, John W. "A review of research on project-based learning." (2000): 2008.

${ }^{10}$ Mills, Julie E., and David F. Treagust. "Engineering education-Is problem-based or project-based learning the answer." Australasian Journal of Engineering Education 3, no. 2 (2003): 2-16.

${ }^{11}$ Plumblee, Jeff, Dylan Bargar, Claire Dancz, Leidy Klotz, and Amy Landis. "Teaching Social Entrepreneurship through a MOOC Format." (2016)

${ }^{12}$ Curtin, Alicia J., Diane C. Martins, and Donna Schwartz-Barcott. "A mixed methods evaluation of an international service learning program in the Dominican Republic." Public Health Nursing 32.1 (2015): 58-67.

${ }^{13}$ Huff, James L., Carla B. Zoltowski, and William C. Oakes. "Preparing Engineers for the Workplace through Service Learning: Perceptions of EPICS Alumni." Journal of Engineering Education 105.1 (2016): 43-69.

${ }^{14}$ Blumenfeld, Phyllis C., Elliot Soloway, Ronald W. Marx, Joseph S. Krajcik, Mark Guzdial, and Annemarie Palincsar. "Motivating project-based learning: Sustaining the doing, supporting the learning." Educational psychologist 26, no. 3-4 (1991): 369-398.

${ }^{15}$ Scott Stanford, M., Lisa C. Benson, Priyanka Alluri, William D. Martin, Leidy E. Klotz, Jennifer H. Ogle, Nigel Kaye, Wayne Sarasua, and Scott Schiff. "Evaluating student and faculty outcomes for a real-world capstone project with sustainability considerations." Journal of Professional Issues in Engineering Education and Practice 139, no. 2 (2012): 123-133.

${ }^{16}$ Zoltowski, Carla, William Oakes, and Leah Jamieson. "Equipping multi-disciplinary student teams to manage multi-semester design projects." age 10 (2005): 1.

${ }^{17}$ Cancedda, Corrado, Paul E. Farmer, Patrick Kyamanywa, Robert Riviello, Joseph Rhatigan, Claire M. Wagner, Fidele Ngabo et al. "Enhancing formal educational and in-service training programs in rural Rwanda: a partnership among the public sector, a nongovernmental organization, and academia." Academic Medicine 89, no. 8 (2014): 1117-1124.

${ }^{18}$ World Health Organization. Guidelines for drinking-water quality: recommendations. Vol. 1. World Health Organization, 2004. 